CONTACT DETAILS

MARTIN KOVAN

8/221 Pelham Street

Carlton 3053

VICTORIA

e-mail: martinkovan@hotmail.com

ph: 0408201345 
Abstract: This essay considers some meta-ethical questions that emerge from a consideration of the phenomena of terrorism in the context of Buddhist metaphysics: what, in the Buddhist view, ultimately causes terrorism (and its subsidiary effects)? What resources do the Buddhist metaphysical claims of non-self, karma, emptiness and related concepts bring to a meta-ethical understanding of terrorism and its effects?

Keywords: non-dual ontology; Buddhist meta-ethics; non-self; Buddhist hermeneutics; terrorism

\section{'Freedom/Ignorance': Buddhist-ontological non-duality and metaethics in an age of terror}

\section{On 'non-self'}

To ask the question, as Buddhism does, 'What is my true nature?' is to ask many questions. It is to suppose of something that it be something other than it appears to be. It is to suggest a non-evident dimension of its being as an ultimate definition for its apparent, though inadequate, given nature. It is to possibly ask a question that requires no answer (or that cannot be answered) because the question does not signify a really-existing condition. In reference to the true nature of anything, or to objective events, it would seem to demand an analysis that the event in its ordinariness itself defies: the 'true nature' of a barking dog, for example, or a car-accident, each distinct phenomena, would seem to make very little difference to the lived-experience of those things.

Yet if it could be claimed that knowing the 'true nature' of such events fundamentally modified my experience of them, I would failing that knowledge be powerless to assert a final judgement on them. That is, what they finally 'are' or 'mean', what they are representations of - the dog's emotive production of noise, the sudden annihilation of the car and its loved occupants-remain an interpretive exercise relative to my own changing, conditioned, ephemeral or uncertain understanding. 
In lived-life, we don't always need (or want) to interrogate our received interpretations of recognisable events: they function as they do, presumably for the good or bad, but apparently meaningful, reasons that invariably follow upon them. But my interpretation of my 'self,' of the awareness that in the course of a day moves through a plethora of rapidly changing effects, moods, and emotional, cognitive and energetic 'states', presents a more directly ambiguous text to decipher.

Who am I in this abundance of changes, modifications, minor crises of diurnal consciousness? This question implies a slew of others: if I have a 'self-nature', if there is a habitable space capable of awareness within this shifting kaleidoscope of self-reflection, is it something that abides distinct from the shifting pattern itself? Or is it a very part of the weave of the pattern, a precondition to its constant transformation? Do I inhabit my self-reflexivity, or are it and 'I' functionally equivalent? Is my 'true nature', should it exist, a place, a topographic dimension of myself that I can reach, that by definition is 'readable' (by way of a technique, an intention, an inspiration, a meditation?) If 'that' self is my true-self, is it capable of being lost, or only temporarily lost sight of, being there all along? Is it, by variation, not another identity, or thing, or object (of consciousness), but rather, as the Buddha tried to express, a not-thing, a dynamic, a process, without fixed, definite or discoverable identity, a provisional identity, paradoxically, of no-identity?

If these questions seem momentarily worthy of enquiry, it is something to be surprised at when in the phenomenal world in which they can be asked they amount to nearmeaningless questions. In that world, where a continual struggle for survival in a densely competitive economy effectively answers the question of the purpose of the self, 'what' I 'am' at any given moment is precisely how my organism is engaged in seeking and securing adequate shelter, nourishment and, when things are going well, companionship. That self rarely stops to question whether the status of its perceptions is one that could signify a possible absence of meaning, Cartesian or otherwise.

Because the question 'What is my true nature?' is also a question about value, a plumbing of human meaning that implies a richer answer to the multiple answers my empirical self might volunteer: that my nature is to be alive, active, useful, happy, hungry, satisfied, desirous, gratified, fulfilled, compassionate, funny, wise and so on. At any time one or all of these characterisations of self may appear adequate answers to the question 'What is my true nature?' Perhaps, for most, there are no other such answers. 
Why then did the Buddha find it necessary to repeatedly ask this question of his fellow men and women? What difference would his entreaty have been intended to make to the quality of their lives? Despite his aversion to typically metaphysical conundrums, could his 'not-self' merely confuse them, and set them off in search of practically unattainable goals? What do the metaphysics of the Buddha have to do with us?

The classification of the limits of human consciousness, for many, can be safely left to the researches of neuropsychology, or the philosophy of mind. The human world, as it is, goes on with its own more imperative business of surviving, succeeding, failing, starving, growing more rich, growing more poor. Who I am is to be functionally equated with the particular trajectory through which psycho-physical states my organism passes. As a person, I am neither an animal nor a divine spark of God nor even a judicious combination of these: I can be reduced to none of, nor a combination of, these terms. To all possibility I am a million and one conditioned qualities, subsisting in none, resting in none, finally becoming none in a conclusive summation of them all, and so peculiarly constituted by a very real sense of lack, of nothingness, as well as whatever self-description myself and the world can consensually agree to.

I am both something and nothing, with a curiously functional integrity subsisting in my contingent nature. Contingently, my hand may be bitten, or not, by the barking dog, or this body very possibly have perished in the car-accident smouldering by the side of the road. Outside of or beyond those particular destinies, for example, what is there in me, or that I am, that constitutes myself more truly?

The nuance, the Buddha suggests, lies in the space between what happens to me, and how deeply I identify with events. Nominally I am the being who does, or does not, avoid being randomly bitten by an angry dog, or dying in an absurd car-accident. (Neither of these events are absolutely random nor absurd: they are interpretations I bring to my current understanding of them). Yet I am not the victim or survivor who suffers, or rejoices, in the same events. Nor am I/am I not either of these in any definitive sense. In c. BC 483 the Buddha himself, in one telling, died from food-poisoning caused by turned pork; but by then he had spent forty years teaching that he was not the body which could thereby die, nor the subjective self who could thereby suffer its death.

He had also taught he was not an eternal and all-abiding Self (the Vedantic Atman) that was neither mind nor body but its own gloriously self-subsisting entity of a-temporal 
awareness. The Buddha denied his actual nature was any of these things, and nor was it nothing-at-all. Nothing-at-all for him was an abstract category, dear to nihilism, which he was also concerned should not be equated with his own suggested non-self (anattā), the emptiness of which has, especially in its initial Western $20^{\text {th }}$ century transmissions, been mistaken for a version of Absence, Void, Nothingness or Negation, again as a conceptual entity which can stand in contradistinction to the apparent existence of things.

The Buddha's anattā was, and is, a far more subtle sign. That is, the Buddha says, your true nature is not even a 'non-self,' as if that could be an oppositional thing to a 'normal' self, but a different understanding of the self you already are: a revision of how you conceive your 'self', if you are already able to self-divide and observe an object 'self' from another subject self. Carry that process of self-observation into an infinite series, the Buddha claimed, and you will finally (though 'finally' can never come) be unable to confidently stop and rest with a single observing self and identify/reify yourself as such. The exercise, he suggested, was impossible, endless, literally irresolvable.

Except that the pragmatic response - to be tested by anyone with enough curiosity was to conclude that such a self could not be found. For the Buddha it clarified and resolved a slew of anguishing questions about who he (thought he) was and why he suffered. That is, it implied that the field of human suffering lay not so much in unavoidable contingent factsthe most fundamental of them being old age, sickness and death-but in the configuration, and complex, of 'self' who experiences them. Mark Siderits writes that

existential suffering arises from the assumption that there is a 'me' for whom events can have significance [...] Now suppose it could be shown that while there are experiences that make up a lifetime, those experiences have no owner. There is no 'me' whose experiences they are. In that case the conviction that my life should have uniquely special significance to me would turn out to be based on a mistake. For experiences in my life to have meaning, there must be more than just the experiences, there must be something separate from them for which they have good or bad meanings. Without belief in a separate self, existential suffering would no longer arise. Such suffering requires belief in something whose demand for meaning and significance is violated. It requires belief in a self (Siderits, 2007: 26-27).

The notion non-self lies at the heart of all Buddhist ethics, which takes a concomitantly de-reified stance towards all forms of, for example, righteous violence. Strongly opposed to all acts of violence, Buddhist teachings analyze it in psychological terms as the necessary 
product of greed ( $r \bar{a} g a)$, hatred (dveșa), and especially delusion (moha). More specifically, violence has its roots in the false apprehension of a self (ätman) and a desire to protect that self against 'others' who are thought to threaten it. To act out of violence, for Buddhism, is to respond to an illusion from the illusive vantage of an illusory self.

The metaphysics of non-self is only the subtext to a transitive ethics which it supports, and these fundamental Buddhist responses to violence, and terrorism specifically, are neatly summarized by the Buddhist ethicist Damien Keown in three main points:

First, that we must try to understand fully the causes that have led to the present situation. The doctrine of dependent origination (pratitya-samutpāda) teaches that all situations are the product of a complex nexus of causes and conditions, and lasting solutions cannot be found until we fully understand the reasons why situations arise. Second, that we must respond to aggression with compassion as opposed to hatred; and third, that violence will only lead to a cycle of retaliation and make the chances of peace even more remote (Keown, 2005: 82).

This essay won't pursue the ethically normative or psychological applications of the Buddhist Eightfold Path, vis-à-vis its goals of a transformation of the empirical self towards a more enlightened relation with the samsaric world (this has been pursued at length by others; see Loy, 2009: 155ff; Hershock, 2003). 'Enlightened violence' is an oxymoron, though proactive violence is evident in Buddhism historically, and its complicity in the Japanese fascism of World War Two has, in an exceptional example, been fully exposed, as have similar transgressions in Sri Lankan Buddhist nationalism (Degalle, 2006). It is also possible to theorise a metaphysically redemptive understanding of violence in the Mahāyāna context of the bodhisattva path, as I have done elsewhere (Kovan, 2009).

In the context of radical violence however, or even its more normalized forms such as the well-entrenched global industry of animal slaughter, economically-rationalised massstarvation or mass-attrition from preventable disease in the third world, it is possible to register here a pragmatic skepticism around the near-secular common-sense of normative Buddhist ethics (such as that summarized by Keown above), without thereby justifying violence.

While metaphysically persuasive, Buddhist anattā could also be seen as ethically reductive or exclusionary, leaving the brute reality of human violence largely intact on its 
own ground. It might also prove socially negligible, despite admirable engaged Buddhist movements for social change, and especially in its Asian homelands, if only in view of the phenomena of an institutionalized political, class-prejudicial and socio-economic violence that successfully demonstrates an almost imperative human relation with aggressionmediated power. Does saṃsāra stretch so interminably far, or is it that, as Girard suggests, more unconsciously sacred values are at stake in its terrible delusions?

Nevertheless, if the Buddha had done no more than accurately observe to how great a degree the complex of self was an agent for its own suffering, his teaching would be already a deeply insightful contribution to practical psychology. But he also proposed that all suffering as suffering, could be interrogated from the bases of its causal origins, and given adequate epistemic and experiential insight (the acquisition of this adequate knowledge dependent also on morally good states of mind and body), conclusively seen into, seen through and dropped forever. The Buddha, in truth, answered the question of 'What is my true nature?' with the claim: Your true nature is that nature which is free of all possible suffering. The story (of liberation) by no means ends there, because that true nature points to the true ends of life as such, its telos in ultimate freedom.

\section{On Freedom}

Freedom begins as a yearning in which the vagaries of ordinary consciousness are conceived as inadequate to a full human potential for happiness. The contingent mind develops an outrage towards itself; it cannot accept its own failures of power, strength or nerve in the face of circumstance. It recognizes the ways in which there is always a possible reparation, a salvaging, or a bare chance for perseverance. At best, in the face of crisis, there is a small but incandescent territory for the miraculous, where adversity even provides the conditions for a definite grace: those crippled in the car-crash take on a new lease of life, an AIDS patient discovers a depth and radiance of spirit that might otherwise have remained closed to him. Disaster becomes a site for the redemptive insight, and while seemingly compromised, the heart of life is deepened or even enhanced in previously unimagined ways. 
In these contexts the ongoing fact of life provides for a redemptive space: the convalescent's room of the open-ended future, where any kind of recovery can conceivably take place. But life is also a terminal crisis. It is not certain that the ongoing crises of aging, sickness, loneliness or deterioration can be contained, repaired or at best, reversed in a recovery-room of the afterlife. Destiny remains on this side of failure, viewed in terms of the striving (conatus) of the organism towards self-regeneration and power throughout the course of its healthy functioning. The reason-for-being of the body has been always to maintain and enhance its strength, beauty and procreative potential, until that entire superstructure of being begins to be dismantled in the face of impermanence and extinction.

The mind of the body, that has endowed the body with character and grace and a hypothesis of the immaterial, cannot willingly appropriate the same total reversal of will. It is more than an outrage of its habitual functioning, it is a dismissal and denial of its seeming nature: that it has no certain use-by date, that it appears to have all before it in the way of happiness, imagination, the creation of things of value or beauty. The redemptive space, for the mind, would conceivably exist in a dimension it must only attune itself to, and abide in, for the shocking transgression of biological dissolution to be seen as an intelligible, but not absolute, condition.

Without the totalising future of redemption, which almost guarantees in its very eternity an inevitable stumbling across freedom and its happiness, what remains is the totalisation of this single life, the materialist good cheer to keep the machine running smoothly, at least for future generations, or the sceptical doubt as to the ultimate value of such an arguably flawed (that is, auto-destructive) system. Dostoyevsky's courageous $19^{\text {th- }}$ century nihilists and mystics thrashed out the implications of the dualistic spectrum, once God had died. Existentialism carried on the dyadic discourse by locating a self-rescue in the individual herself who must, denied any choice (and failing suicide), stand absurdly, but nobly, against contingency. $21^{\text {st }}$-century religious fundamentalism, especially in its acts of terrorism, hovers hauntingly in the dead-center of the same dualistic divide between absolute Transcendence and absolute Nihilism, so that each side in its extreme engenders, then becomes, the other.

Late-industrial capitalist materialism sidesteps the shopworn debate (that surely belongs to another, more neurotic time), by vaguely subsuming existential angst in the redemptive powers of technology while it watches the biological bases for integrity falter and 
split at their planetary seams. The givens of the biosphere and its life-support systems have never been in such globally acute crisis, yet the same materialism embarks on a program of denial that appears to be deceiving itself into a technocratically-mediated belief in speciesimmortality. (Indeed anti-aging biotechnologies that currently propose indefinite lifeextension are already taken as an unproblematical given, an instrumental challenge with frequently little if any reference to the hubris of human-engineered omnipotence. That moralreligious issue, too, doubtless belongs to a more old-fashioned time.)

The Middle Way of the buddhadharma opens up, at this late point, in an attempt to redress some of the anthropomorphic imbalance, and point to the freedom from suffering in which it foundationally grounds its metaphysics of optimism. Given an accumulation of moral virtue (positive karma) in this life, a next one will allow for its good effects to be manifest, until an incremental progress reaches the ultimate flowering of full spiritual awakening: buddhahood. Social, economic and ecological altruism is clearly a necessary correlative to this process. Buddhism remains one of the most perennially redemptive visions, insofar as it might be achieved not by supernatural deliverance or technological instrumentality but by the simple efforts of the (only provisionally real) will of the individual in her society. It is not necessary to prove its truth-claims to be inspired and transformed by them.

Buddhist redemption, also, does not begin only in the good effects achieved now, taking form in a next life. In its more subtle interpretations, the dharma describes the redemptive moment of the very present, in its essence, as the pure awake-ness of consciousness itself: the mind of the Buddha shining-through, however obscured to the individual self-awareness, in the mere awareness of pedestrian experience. Consciousness itself, as awake-ness, already is bōhhi-mind asserting its own potential for Awakening. Human intelligence, unlike most other biological forms (and within the spectrum of sentient beings therefore the most privileged), can so render meaning to itself, even if that meaning engenders suffering. In human ignorance, then, spiritual awakening is inherent; in its suffering, the freedom from suffering. Human consciousness inhabits a space of fertile paradox: it suffers, but only to suffer beyond its suffering. It lives, and dies-yet only to live again beyond its death: in future lives, and in every moment.

The Buddha would not be denying there are suffering subjects living/dying in the multifarious garden of sentient life-from whole endangered species to a helpless child in a 
place of famine. His point would not be that suffering does not exist at all. His concern would be to indicate that in the garden there are all manner of living things, and that each literally requires the other to define their own existence, that where there is pleasure there must also be its absence, where suffering also an ephemeral joy. Because these things all possess no final true nature, they require every gradation on a spectrum of possibility to be able to exist at all. Each literally justifies the other, despite all value-judgements discerning between them.

The Buddha's concern would be not to level, homogenise or eradicate the existence of these often opposed, even contradictory, things. His concern would be to dig beneath the garden itself, and deconstruct its parts, to enact an excavation into where the suffering of contingent things could be definitively found. And his discovery, as before, would be to assert after proper enquiry that where no discreet thing can in fact be found, no identity to possess a self, there no suffering could be found either, though the multifarious garden keep on growing, dying and regenerating in an ongoing cycle of change, and pain, and freedom.

It would be to say that the true nature of contingency - the conditionedness of the self and its suffering-is that it has no true nature. That is, that it is by nature open to modification, and not fixed in an objective-subjective binary of immovable force. Contingency too, then, would be only another site for hermeneutic exercise (like the self, and the experience of the self), and the suffering entailed in contingency also an object for interpretation. It would be up to us, the Buddha maintained, perhaps optimistically, to learn to revision suffering, and above all, live it differently: as an ethical exercise. Suffering would be the raw material for acquiring the existential frame of interpretation that could most adequately explain the appearance of things and events that, on the one hand, must remain obscure or even absurd, and so proof of meaninglessness, or on the other, disclosures of a value (however germinal) adequate to both their contingent appearance and the suffering constitutive of them.

If it would be necessary to then characterise what the true nature of the self and its suffering is - that is, the closest we can come to epitomising its essential value - it would be that the liminal space of freedom, between such a judgement of meaninglessness and one of ultimate value, is the most dynamic field of the mind, its place of authentic adventure: life, in fact, such as it is, and in its suchness (tathatā). For the Buddha, it would be up to us to discover where exactly on the spectrum between a total determinism (and its unending suffering), and an open-ended idealism (and its absolute freedom), we were willing to stand. 
The true gift for him — the irreplaceable, truly human birthright—was that the choice was not merely ours, as individuals and as a species, but that we have any choice at all.

\section{On Ignorance}

In the liminal space where certainty and intention have both dropped away, where the most insistent of the self's voices have lost the war of attrition against the vastness of not-knowing, nothing and everything seems possible of achievement. To float inside open-ended uncertainty - about self-nature, truth, or absolute wisdom - is to occupy a field of fertile negation. That is, it can be asserted that identity lies ultimately nowhere in designable phenomena - those things that at any rate hitherto have been taken as the bases for a working self-knowledge. Similarly and just as provocatively, the existence of a salvific being or power is if anything marked by an ambiguity that speaks as much of constructed delusion as of undoubted presence. Nothing is certain apart from uncertainty.

All Falls are configured as losses of wholeness/es, and the Buddha's pointing to ignorance as the loss of a primordial integrity of mind is no less so, and no less mythic in form. Still more, the conceptual web holds only so much substance. In any consideration of the topos of awakening, ignorance as its shadow also calls for recognition, not misrepresented as concept, but de-philosophised, resistant even to psychologising let alone the fixed forms of logos. Awakening can as reasonably be read as a form of return (to forgotten memory) in the same sense that the myths of origination can symbolise a rediscovered unity and seamlessness — of self, and consciousness.

The Buddha's critique of ignorance, as well as formulation of what redeems it, has come down through two and a half millennia to reach Western logocentric civilisation as a form of rational discourse, which in its exposures of the limitations of the conceptualising mind (manas) exceeds the same: the same threshold that Heidegger, Merleau-Ponty or Wittgenstein encountered (at roughly the same mid-century) at the extremes of a certain ontological vocabulary. 
To take seriously that new language wrought by these thinkers is to begin to take seriously the limitations of a philosophical project that attempts to contextualise Mindbeyond-mind within its own frame: it invites a categorial rupture that requires a more sensitive, but no less actual apparatus of enquiry. On the level of philosophical apprehension, Buddhistic no-mind is a radical but natural transgression, another kind of existential leap, taken from that limit at which signifier and signified break down into their constituent empty parts only given place, co-ordination and sustenance by the mental consciousness which constructs them. The Dzogchen tradition of Tibetan Buddhism focuses especially on this access to the trans-conceptual and non-intentional nature of mind (rigpa).

The intuitive leap from the quasi-terra firma of logos, then, is a return into the wild terrain of origins. The Buddhist poet Gary Snyder calls it Wild Mind, the noospheric correlate to the wilderness of the biosphere, which again accentuates the return into prerepresentational, that is, the understanding that was always there prior to discrimination, discernment, the identification with a self only able to perceive dualities, reflections, cherished qualifications, rather than the empty-full, unified (and/or polymorphous) field which ostensibly grounds them all. The origin becomes the 'ground,' and the 'ground' as the most fundamental locus for the organism and the mind which unlearns its way 'back' there, in its true home and place of emergence, its pre-natal matrix of potentiality.

Yet the mind, the animal, the sinews of being soon tire, and relinquish search: answers themselves are a weight not to be borne, and false ones even moreso. It seems far wiser, and truer, to live in the light of full knowledge of impotence, yet thereby of the essence of full autonomy. The absurd man, it was considered, could survive by virtue of a willing capitulation to hopelessness combined with a will to enact ultimate impotence as provisionally useful endeavour. The recognition of the sentence allow the numbered days to be given over to the happy fiction of a moral agency: such meaning, in the face of evil and injustice, Camus thought, is meaning enough.

So it remains, for the mind of the early-21st century. Morality, for that mind, remains a psychic structure that bifurcates experience and human action within it into one or another side of a dual divide. It evidences most gratuitously the proliferation of conflict over and against religious, racial, economic and ethical evil, defined freely by either side. Humanity wants to be moral, but perennially requires an enemy to be so. Righteousness without a front of resistance is an empty rhetoric, and a million ready wills hunger for the cause that might 
set them against the assumed force of oppression, so that another battle for truth, liberty, democracy, justice or God might be won.

The slave revolts and sets up as the new master, and the oppositional duality that is the single most ubiquitous yet speciously reductionistic weapon of conceptualisation keeps the bloody, rusty cranks of history turning. As God's will speaks, tens of thousands more of malnourished children die, disenfranchised 'minorities' define themselves only by reference to a dubious enfranchisement, and the ecological balance of the biosphere buckles under exponentially increasing blows of abuse.

It is not apocalyptic, which is only another projection of extreme duality: it is merely a breathtaking capacity for quotidian forgetfulness, a looking the other way, that allows a split-identity narrative (along with a basic negligence of those in need) to drag interminably through its moves until a next, and a next, inevitable crisis. The almost blindingly unthinkable catalogue of the 20th century, from World War I to Hiroshima and Auschwitz to Rwanda and beyond, let alone those of earlier ages, is hard evidence of a deep-ignorance difficult to deny. There is the proof, the sages say, pointing to genocide, racial hatred, religious warfare, even that pseudo-enlightened form of dominion that goes by the name of liberal democracy righting the injustice of the politically oppressed, while it scourges them of their dignity, resources and autonomy.

At such a point despair would need to be accepted as the authentic response to a single, defining conclusion: that human culture, and the consciousness that informs it, reaches a wall beyond which it is, terminally, unable to move. History is not a progress in ethical terms, it is a cyclic and repetitive demonstration of a continual failure of the race to genuinely surmount the gratuitous terrors of self-imposed suffering.

It is a tired litany to repeat, here and anywhere, how far historically good intention can be read as a proof of failure: today we salvage what is left of the philanthropic programs of earlier dual-divides between master and slave, colonist and colonised, codifier and codified. Yet the contemporary language of war and its various forms of aftermath still hold faith in the efficacy of such historical measures: 'democracy,' once installed, is able to 'reinstate' the liberty of a people, and the 'restructuring' of human freedoms allows for the 'reabsorption' of diverse elements into the 'rehabilitation' of the whole. It is up to the redemptive master to 'remake' reality, and remake it as a primary proof of 'unification.' 
Conflict itself, as its end aim, advertises the vision of unity, of brokenness-madewhole, in its ideal eye. The weak require the strong, and only the strong have the means, to institute the resurrection of all original goods. If power was unable to avert the loss of equilibrium between competing ills before, now it will fight solely on the side of the good of all: the unitary vision that, itself a Utopia, remains a metaphor that the oppositional poles of a universal will have, alone, as a single term to justify their necessarily non-unitary selfinterest. The dream of wholeness, of totality, the mandala principle, becomes not merely the unspoken yet guiding figure of a lone, struggling self, but of a collective psychic entity: a nation, as well as that nation's enemy. A collective identity burns, even to the death, for unitary consciousness, but like an auto-destructive automaton, requires the subjugation of the Other in order to bring the phantom of totality to a mirage-life. At least two major faiths, unlike the Buddhist, call for the salvation of his brother, depending on his brother's submission to his own faith.

Religious man seeks universal brotherhood, but stumbles continually in the shackles of his own adherence to a dualistic conceptual, linguistic and religious model of truth. The model itself, over thousands of years, barely loses its sheen, while millions have died, as so many disposable rags, for the sake of its immaculacy: Christian or communist, it is not even the model itself that has necessarily counted, but the sheer human willingness to bow down before its universal judgement and submit to a willing, and more often unwilling, martyrdom in its name.

Who has benefited from such exertions, or can the benign alleviation of suffering still be spoken of in such terms? If so much religious as well as secular response to worldly suffering proves so often to be an unintended displacement of the sources of that suffering, so that the response to poverty for example becomes an exercise in microeconomic adjustment to an existing structure able to continually defer responsibility, exactly where responsibility for poverty may be placed remains a considerable question. The seemingly intractable global crisis of inequities of wealth, self-determination and power, racial and cultural sovereignty, or economic and intellectual hegemony, turn in cycles of never-completely realised causal hubris. Thus-sampsāra. 


\section{On Terror}

In transcendental religion, there is a renunciation, and a sacrifice: it is the body, at the very least, that must be offered up. Salvation cannot take its great strides, when the spiritual libido is subsumed in an endless, but unsatisfied, adoration of form. Form, as much for the Greeks as for some Asian (especially Hindu) metaphysics, was appearance, which being changeable and subjectively conditioned, was fickle, deceptive and ultimately illusory: $m \bar{a} y \bar{a}$. As illusion, the play-world of ignorance, it is that mind-projected fiction where Being has become obscured in change, in the loss within change, and the suffering within loss. The most powerful after-effect of the disabusing of the poor-sibling body is the extent to which it perpetuates the parallel master term of duality also. It allows for the project of terror to find its ready scapegoat: the (sacramental) Body of the Other that must be destroyed before the religious Ego can be granted its Salvation.

It is also possible to understand duality as historically determined and determinable (in epistemology, science, law, political-ethnic conflict, punishment, anthropological and sociological hierarchies generally), identifiable as such and historically temporalised (David Loy does just this in A Buddhist History of the West). It might be an instructive exercise to unpick the construction of duality as a historical determinant of spiritual experience: how far it is a heuristic metaphor designed to act as the binary Geiger-counter to Buddhist and other non-dual truth.

That is, if the human-symbolic (formalized and institutionalised) civilized world has been historically constructed from an ontological default position of dualistic consciousness (hence the reference to the binary conditionedness of many of the symbolic oppositions invoked here, and which contribute in great measure to the intractable conflicts of human societies and their polarized antagonists), from the non-dual perspective the dualistic nature of this constructed (and spiritually ignorant) world actually has the curious function of marking that 'Fall/lapse' into duality (figure-background style) that keeps non-dual awakened consciousness true to itself. Non-duality can also be theorized in its generally (nondetermined and) non-determinable status vis-à-vis the cultural artefacts of dualism. Is it 
possible that extreme ethical aporia introduces a kind of coerced non-dual view merely by force of its extremity and resistance to ethical normalization?

Ethical extremes by their nature perhaps shouldn't be epistemically (or aesthetically) regularized - this is obviously Adorno's fear and claim in his famous reference to 'poetry after Auschwitz.' For non-duality (esecially its Vedantic forms) anything in a dualistic universe is not real, it is indeed a 'metaphor,' Māyā, a veil, a cipher of primordial ignorance. Yet every time the nature of that construction is forgotten by the non-dual adept, the very bad, the worst, the truly absurd constructions of duality can serve to 'remind' him of ontological illusion, what it is, and how it manifests (and the terrible suffering it causes). Hence the metaphor of the spiritual Geiger counter, which loudly alerts the Vedantic advaitin or Buddhist Dzogchenpa to erroneous mind and its inevitable constructions of an illusory, misleading and suffering world.

There are, all too often in spiritual literatures, only two directions to go-towards heaven or hell, towards truth or ignorance, and they are mutually exclusive. In ordinary life (there is no such thing) it is assumed to be difficult, too, to do something which is both good and bad at the same time.

What is remarkable is how pervasive are those 'ordinary' behaviours which can reasonably be described as neither. If spiritual progress, too, must be categorised in either of these two directions, what would it mean to suggest that much of what actually occurs in its name (or under its political auspices) could be seen as neither good nor bad, malign nor benign? What is it to determine, for example, to what degree an action is or isn't of the nature of ignorance, or its opposite? Wouldn't that require another witness-mind able to confidently determine what ignorance, in any context, looks like?

In Buddhism, in fact, this is supposed to be not merely possible, but at the heart of spiritual practice. Meditation, considered as a training in calm discernment, is often understood as the hitting of a moving, unreal target, coming squarely and truly into agreement with what is (and is not), and in terms of form, making the true mark (no-mark). (From such insight of praxis, all the aesthetics of Zen, calligraphy and martial art emerge.)

At the same time, to decide, for a person, is to commit, from out of nothing, to something: the power of the will-even a relative, illusory one-remains a godlike gesture. In the face of adversity it is not often passivity or a selfless acceptance of what is that 
distinguishes human achievement: it is the ability, and the will to manifest it, to persevere, come to the aid of the other, and start again, that epitomises human action. In their spiritual exertions the Buddha and every sage are archetypes of the struggle and supremacy of the will; every Zen monk must submit to a relentless regime even where it is only to finally serve in the surrender of that same will. The $14^{\text {th }}$ Dalai Lama frequently exhorts his large audiences to 'never give up, no matter how hard it may be.'

It is the force of a self, often an individual (think of Luther, Gandhi, Havel, Mandela or Aung San Suu Kyi) that is able to galvanise whole demoralised peoples, a nation, a moribund history. Humanity is never more godlike than when she refuses to surrender to her pain, but stands up against it in an unequivocal act of defiance. Yet the power of the same self can so easily be seen to trip into the delusional hollows of hubris. Rebellion against unjust gods quickly caricatures into Lear shaking a mad fist against them, mired in pathos (think of Napoleon, Hitler, Hussein, Gaddafi or Indira Gandhi). Hubris is to miss-the-mark, lose the center of spiritual gravity, forget that a supposed middle-way still exists.

The buddhadharma makes much of the Middle Way: the golden mean to true insight and true liberation. It is a philosophical shorthand for the madhyamaka dialectic of Nāgārjuna, one of the finest grains of metaphysical statement that intellection (citta) can conjure. The Middle Way is also the ethical imperative that seeks to serve others before serving oneself, but always in proportion to the self's ability to truly do so: the will, the Buddha urged, should be neither too loose nor too tight; the body must be neither starved nor over-sated; philosophical enquiry must serve the practical goals of freedom and not metaphysical hypothesising with no means of verification. Conceptualisation itself should avoid excessive abstraction but also not rest content with rough generalities that miss identifying vital distinctions. Suffering itself can be seen as an acknowledged vehicle for coming to the spiritual path, but once recognised as a motivating force it must be made to serve the needs of intuitive insight, neither justifying nor denying them.

Life, as it happens, will provide all the materials for the self in its transformational journey: necessary to a perfect decimal-point of necessity. We suffer, the dharma seems to tell us, precisely as much as is required for the intuitive mind of liberation to find an answering echo, and deliver the self home. It is only up to us to adjust our existential and conceptually discriminative radar and re-vision the prior terms of interpretation of the data. Nothing, in truth, is wrong, or only appears that way. Nothing is intrinsically awry-the car- 
accident, Hiroshima, the Rwandan holocaust. All is necessary and can even be justified as such. What seems unthinkable can become soberly understood as a radical gift of potential insight.

The defining event of this century, September 11, 2001, can be seen, transparently, in the same light: the Absolute betrays itself, almost predictably, in the appearance of the abject, and horror is truth as much as grace is. No dualistic mind is able or willing to believe nondual apprehension, yet it is there, and if nothing else it escapes the tired binaries of good and evil engaged in a deathly war over the salvation of a dubious entity-man's soul. Political analysis dissects the course of geo-political history that leads, repeatedly, to human impasse, or human victory, depending on which side of various dual subsets the analysis holds to. At the same time there is a painful suspicion that no matter what kind of conclusive explication can be justified, it is still a matter of playing chess with absurdity.

The conclusion, finally, doesn't matter to the given, doesn't, perhaps, mean anything. Theology will try to determine what rationale drives a God to exert his divine will in such terms. Buddhist metaphysics similarly will rationalise via the ripening of the negative karmas that affect a certain group of individuals, and then the cultural, national and political grouping that they identify as. None will be certain, in truth. If they are able to acknowledge their ignorance, they are also likely to suppose they aren't ever able to know. That knowing is not the crucial heart of their experience. That, finally, they don't need to know. The mind that concedes its own ignorance is conceivably a non-dual mind, it is innocent, and it has no agenda with the universe in which it situates itself. Events are their own explanation, a challenge to comprehension as they very often are. All that remains is pure relativity: not a single individual is able to find ultimately adequate reason for what was suffered, for example, in New York City in September, 2001, even if its rests content with various gradations of a rationalizing spectrum.

Regardless of the grievance terrorism presumes to use as justification for such a crime, the act itself far exceeds any possible retribution. It is far too uncanny for that kind of reasoning. What, finally, can it mean to the individual mind that witnesses such extremity? To the collective mind? It suggests that beyond a certain point certain events enter into absurdity and thereby defy human reason. They demonstrate that there is a dimension of experience for which the configuration of the mind, and shared consensual consciousness, has no right of way: that is, it cannot reasonably speak to and with such events, is left speechless, 
spellbound by its recognition of inherent limitation. Into that dimension it can't immediately penetrate or dialogue, though it tries to sincerely. Such events are the profoundest irony because it is exactly their horror, their extremity-that we can legitimately feel outrage towards - that also demonstrate the sheer proof of what is beyond us. And then leave it for us to decipher.

God, for some, shows his true hand, hitherto unseen. For a Buddhist, the morally aporetic is potentially a blinding flash of vajra light: a thunderbolt of the indestructible, diamond-like, non-dual truth of emptiness. 'God' has done the same infinite times before now, everywhere, and every day in an infinite variety of ways, and is doing it again now.

For the Buddhist, again, God is a superfluous equation, if He remains ontologically external to the habitus of the self that experiences, witnesses and suffers. The self can, at least, be grateful that the experience hasn't quite killed it: only the realizing-self can unlock the knot of the reified-self, find out what absurdity still barely means, discover if it speaks a language that has its own reason, a madness its method. The self might decide its experience means little of worth - only bad news, or that nothing is worth such heartache. It might conclude something has been meant, a possible academic gloss that puts experience in context, but doesn't relieve the pain within it. The self, then, does its therapy, emotional work, exercise or whatever it has found to compensate for disappointment and perplexityperplexity above all with its own ignorance. Or the self comes to understand that everything is meant in such experience, and that everything depends on realising it deeply so the same thing never, without a shadow of possibility, ever happens again. The self asks if it is possible to take the reins of existence so powerfully into its own hands not only so that it might truly understand it, but also transform it. The Buddha, again, suggests-yes it is possible, no question, and you must try.

The Buddha's response, as much as the actions of the September 11 terrorists, is a wake-up call, in the most absolute terms there are. The terrorists, from their side, merely have the literally insane, and perverse, compassion to point this out for the benefit of all survivors. They throw it in the faces of the living as the completely necessary and urgent quantity spiritual liberation must attend to, especially, and even, as the terrorists don't know it, and do it out of the purest blindness. To call them evil is an error of self-recrimination as absurd as their act itself under any ultimate analysis. David Loy even goes so far as to 
Let me now carry the argument one step further. Not only are fundamentalists right to be suspicious of [such a] secularism, I believe they are also correct to believe that there is a spiritual war going on. To use the favorite Christian term, there is indeed an Antichrist that needs to be challenged, in fact one that parallels the original coded reference to the Roman Empire in Revelation: the corporate-military-state, which has become the main institutional beneficiary of [the] unbridled secular authority [...] (Loy, 2009: 172).

To describe the other as evil is at the very least to bring my own culpability into question as well. All martyrs - the murderers and the murdered-are each one asking the species that still lives to wake up to how things are, to ourselves, to the extreme suffering perpetuated needlessly by individual and collective conscious existence. The Fallen demand of the rest that they be free from it, the Fall, once and for all. They implore us not to wait. They urge us to take hold of under-exercised human potential and work the mystery of suffering out of the race: the entire story, from the beginning. God can't do it - two-thousand years of misadventure has taught that up to now. We will have to, they repeat, do it ourselves. The individual must take on the task, as an individual. No-one else can do it for them, even where reliable guides, like the Buddha, are found along the way.

Such are the ethics of Buddhist non-duality. New York was visited with perhaps the first truly visible such revelation of the new millenium, though there have clearly been others. It was there to inspire the one, as much as to outrage the other. It did not occur merely as a pretext to apportion blame and go out with a bloodlust to satisfy vengeance: the hubris of recrimination, once again. It occurred to make the self - of ourselves and of our historymore aware than it has ever been of the fact of being at all, and what the self will do with that awareness. What will it mean: to destroy or enlighten? September 11, among other such events, throws the question of Being into the face of being. It asks a basic question: whether it is enough for human consciousness to choose to continue the same repeated story of samsara, continue to throw bombs back and forth across the fence of duality, from the self to the other, and so, in all likelihood, annihilate much that remains of value. Or, on the other hand, for consciousness to begin to lift the entire superstructure of its interpretation, and thus its lived reality, onto an untested level of authentic freedom.

The witnesses are there to keep an eye out for the signs, and no-one can afford to close their eyes to them, to refuse to see anything. If so, truth is already lost - there's nothing to hold onto. There's nothing, the Buddha repeats, and repeats again, to hold onto anyway. But knowing it makes all the difference. In the darkness of ignorance, with the terrorist, I 
won't even know that, which is as bad as anything else could be. Such a blindness isn't worth the price of admission, and it might even be wiser to be in the Falling Tower, when it goes down. Especially if the day comes_-in all possibility — when we are unable, as a species, even to buy the entry-ticket.

\section{$\underline{\text { REFERENCES }}$}

DEGALLE, M. (ed.) (2006) Buddhism, Conflict and Violence in Modern Sri Lanka Routledge, London and New York.

HERSHOCK, Peter D. (2003) "From Vulnerability to Virtuosity: Buddhist Reflections on Responding to Terrorism and Tragedy" Journal of Buddhist Ethics Vol.10, 2003.

KEOWN, Damien (2005) Buddhist Ethics: a very short introduction Oxford University Press, Oxford.

KOVAN, Martin (2009) "Violence and (Non-)Resistance: Buddhist ahim $\bar{s} \bar{a}$ and its Existential Aporias” Journal of Buddhist Ethics, Vol. 16, 2009.

LOY, David R. (2009) Awareness Bound and Unbound: Buddhist Essays SUNY Press, Albany.

SIDERITS, Mark (2007) Buddhism as Philosophy: an Introduction Ashgate, Great Britain. 


\section{University Library}

\section{- M M N E R VA A gateway to Melbourne's research publications}

Minerva Access is the Institutional Repository of The University of Melbourne

Author/s:

Kovan, M

Title:

'Freedom/Ignorance': Buddhist-Ontological Non-Duality and Metaethics in an Age of Terror

Date:

2013-06

Citation:

Kovan, M. (2013). 'Freedom/Ignorance': Buddhist-Ontological Non-Duality and Metaethics in an Age of Terror. Sophia, 52 (2), pp.381-395. https://doi.org/10.1007/s11841-012-0309-1.

Persistent Link:

http://hdl.handle.net/11343/283328 